\title{
DOPADY KORONAVIROVÉ KRIZE NA SMLUVNÍ STABILITU PROFESIONÁLNÍCH SMLUV VE SPORTU*
}

DAVID KOHOUT

\section{Abstract: Impacts of the Coronavirus Crisis on the Contractual Stability of Professional Contracts in Sport}

The covid-19 virus struck the global society with full power in the first months of the year 2020 and the sports industry was not spared from its impacts. This paper looks at the consequences that the pandemic had for the stability of professional contracts, mainly in the field of football and ice hockey; nevertheless, these observations could be applicable to other professional sport disciplines as well. The situation often brought tensions between the well-respected principle of contractual stability in sport and the acute needs of the clubs and players. It could be considered that even if the pandemic fades away one day, it will leave its footprints on the shape of professional sport. Besides general discussion of the legal consequences of the covid-19 pandemic for professional contracts this article also seeks to provide practical input by drafting a model covid clause for future professional sport contracts and by considering other possibilities of reflecting unforeseen global instances of force majeure in athletes' agreements.

Keywords: sport; professional contract; covid clause; coronavirus clause; contractual stability; Court of Arbitration for Sport; vis maior; FIFA Regulations on the Status and Transfer of Players; COVID-19 Football Regulatory Issues

Klíčová slova: sport; profesionální smlouva; covidová doložka; coronavirová doložka; smluvní stabilita; Rozhodčí soud pro sport; vyšší moc; FIFA Regulations on the Status and Transfer of Players; COVID-19 Football Regulatory Issues

DOI: $10.14712 / 23366478.2021 .16$

\section{1. ÚVOD}

Koronavirová krize zasáhla prakticky všechny oblasti lidské činnosti. I sportovní aktivity byly opatřeními přijímanými orgány veřejné moci utlumeny v mnoha směrech.

Vzhledem k mnohotvárnosti sportu je možno hledět na dopady pandemie z nejrůznějších perspektiv. Opatření v České republice i v zahraničí se tak dotkla jak

\footnotetext{
* Tento článek zohledňuje právní stav k 31. 3. 2021 a vznikl v rámci projektu UNCE/HUM/034 Závislá práce v 21. století - otázky a výzvy na Právnické fakultě Univerzity Karlovy.
} 
organizovaného, tak neorganizovaného sportu. Z povahy věci byla opatření zřetelná ve větší mîre v kolektivních sportech, v řadě směrů však cílila i na individuální sportování, kdy i individuální amatérští a neorganizovaní sportovci v počátečních fázích protikoronavirových opatření podléhali povinnosti např. nosit roušku při výkonu sportu, popř. jim byla uzavřena sportovní zařízení. V kolektivním i individuálním, amatérském i profesionálním sportu byly zastaveny veškeré organizované soutěže a omezeny tréninkové možnosti. Vzhledem k povinnému uzavření sportovních zařízení i omezení shromažd’ování osob došlo již na jaře roku 2020 k zamezení i neorganizovaných kolektivních sportovních aktivit jako třeba volejbalových či fotbalových setkání mezi přáteli.

Omezení se z povahy věci dotkla jak aktivně sportujících fyzických osob, tak také právnických osob provozujících sportovní zařízení či organizujících sportovní podniky v nejširším slova smyslu. U nich v nemalé míře došlo v souvislosti s přijímanými opatřeními $\mathrm{k}$ finančním ztrátám či nevratným nákladům v podobě zmařených příjmů za pronájmy sportovišt', startovné nebo za přípravu a propagaci nakonec neuskutečněných sportovních akcí. K částečnému vyrovnání těchto ztrát umožnil stát těmto subjektům čerpat prostředky z některých kompenzačních programů, přičemž specificky pro oblast sportu šlo v roce 2020 o program COVID-Sport a COVID-Sport II. ${ }^{1}$

První program však cílil primárně na subjekty nezaložené za účelem zisku (tj. ve sportovním prostředí typicky spolky²), zatímco právnické osoby fungující ve sportu ve formě obchodních korporací ${ }^{3}$ musely zpočátku podporu z veřejných prostředků hledat především v obecných programech zaměřených na kompenzaci nevratných nákladů, které musely i přes zákaz či omezení výkonu své obvyklé činnosti vynakládat, a to včetně případného příspěvku na úhradu mezd zaměstnanců. Teprve program COVID-Sport II vyhlášený v listopadu 2020 je zaměřen na podnikající osoby ve sportu. V únoru 2021 pak Ministerstvo průmyslu a obchodu vyhlásilo program COVID-Sport III určený na podporu lyžařských areálů. ${ }^{4}$

V případě profesionálních sportovců, kteří vykonávají svou činnost v kolektivních sportech v České republice v naprosto převažující mîre jako OSVČ mimo úpravu zákoníku práce, ${ }^{5}$ nemohly kluby na jejich měsíční odměny splatné bez dalšího během výluky

1 Výzva Národní sportovní agentury Program podpory sportovních organizací postižených celosvětovou pandemií COVID-19 „COVID-SPORT“, č. j. NSA-0276/2020/01, resp. výzva Ministerstva průmyslu a obchodu ve spolupráci s Národní sportovní agenturou Program podpory podnikatelských subjektů v oblasti sportu postižených celosvětovým šîřením onemocnění COVID-19 „COVID-SPORT II.“, č. j. MPO 591101/20/81200/01000.

2 Viz § 214 a násl. zákona č. 89/2012 Sb., občanský zákoník (dále jen „OZ“).

3 Typicky se jedná o profesionální sportovní kluby působící na nejvyšší úrovni soutěží v hlavních sportech, jako jsou fotbal či hokej. Srov. např. čl. 45/A odst. 1 Klubového licenčního řádu Fotbalové asociace České republiky [online]. 2019 [cit. 2021-02-20]. Dostupné na: http://www.clublicensing.cz/wp-content/uploads /2020/02/CZE-KLUBOV\%C3\%9D-LICEN\%C4\%8CN\%C3\%8D-\%C5\%98\%C3\%81D-Edice-2019.pdf.

4 Program podpory podnikatelů postižených celosvětovým šířením onemocnění COVID-19 způsobeného virem SARS-CoV-2 „COVID-SPORT III Lyžařská stř̌ediska“, schválený usnesením vlády č. 32 ze dne 11. ledna 2021.

5 Srov. k právnímu postavení profesionálů v ČR jako OSVČ rozsudek Nejvyššího správního soudu ze dne 29. 11. 2011, spis. zn. 2 Afs 16/2011; či rozsudek Nejvyššího správního soudu ze dne 13. 7. 2017, spis. zn. 6 Afs 278/2016-54. V odborné literatuře srov. např. BĚLINA, T. Jsou právní vztahy profesionálních sportovců závislou prací? In: PICHRT, J. (ed.). Sport a (nejen) pracovní právo. Praha: Wolters Kluwer, 
sportovních soutěží na základě opatření pro boj proti koronaviru čerpat žádnou podporu, a to až do doby vyhlášení programu COVID-Sport II, který tuto možnost zavedl i zpětně až k 12.3. 2020. ${ }^{6}$ Profesionální sport v ČR se po dobu minimálně celého jara dostal do situace, kdy klubům vypadly př́ijmy především ze vstupného a sekundárně v některých př́padech i z vysílacích práv, avšak nadále pro ně platila jejich primární povinnost hradit hráčům podle profesionálních smluv jejich odměny, a to i v době úplného zastavení soutěží. Bez v té době jakýchkoliv relevantních dotačních či kompenzačních nástrojů k pokrytí hráčských odměn se profesionální sport ocitl v obtížné situaci, kterou musel řešit vlastní cestou. ${ }^{7}$

V dalším textu se zaměříme na to, jakým způsobem se vyrovnávalo sportovní prostředí s nastalou koronavirovou realitou, a to specificky ve vztahu $\mathrm{k}$ jejím dopadům na formu a plnění profesionálních hráčských smluv uzavíraných mezi sportovci a kluby v kolektivních sportech. Cíleno bude hlavně na fotbal a hokej v České republice, a to i v mezinárodním kontextu v rozsahu, ve kterém je mezinárodní sportovně-právní úprava vzhledem k pyramidální struktuře sportovního odvětví podstatná i pro obsah smluv uzavřených např. v nejvyšší fotbalové či hokejové soutěži v České republice. Koncem tohoto příspěvku bude načrtnuto, jak je možné očekávat, že koronavirová krize ovlivní formát profesionální smlouvy ve sportu do budoucna (nebot' i v současné době, kdy se profesionální soutěže za specifických podmínek mohly obnovit, je nap̌r. nadále vyloučen či omezen přístup fanoušků na stadiony a př́ijmy klubů tak nadále budou snížené). $\mathrm{V}$ této části bude představeno několik $\mathrm{v}$ úvahu přicházejících přístupů včetně modelové „covidové doložky“ pro profesionální smlouvy.

\section{SMLUVNÍ STABILITA V PROFESIONÁLNÍM SPORTU OBECNĚ}

Je samožrejmostí, že sport podobně jako prakticky veškerá lidská činnost není vyňat z působnosti práva. Napříč jednotlivými zeměmi se setkáváme s různými přístupy, jak je sport v obecném právním řádu reflektován, přičemž v některých státech se tak děje prostřednictvím poměrně podrobné speciální právní úpravy, ${ }^{8} \mathrm{v}$ České republice naopak převládá doposud př́śtup s pouze minimální speciální zákonnou regulací vztahů vznikajících ve sportu. Tento minimalistický zákonodárný přístup ke sportu v České republice se v zásadě omezuje pouze na zákon č. 115/2001 Sb., o podpoře sportu, který však přes postupné dílčí novelizace zcela opomíjí oblast soukromoprávních smluvních závazkových vztahů ve sportu a je předpisem ryze veřejného práva. České sportovní prostředí proto musí v praxi pracovat s obecnou úpravou smluvních vztahů obsaženou

2014, s. 71, 74; ŠTEFKO, M. Fotbal a hokej výkonem závislé práce s přihlédnutím k německé úpravě. In: PICHRT, J. (ed.). Sport a (nejen) pracovní právo. Praha: Wolters Kluwer, 2014, s. 104-105.

6 Lidově řečeno takřka ,,s křížkem po funuse“. Zda bude z prostředků získaných z této výzvy část převedena dodatečně přímo hráčủm, není jasné. Současně dotační program je omezen limity, takže není a v př́ípadě svého pokračování do budoucna nebude sám o sobě řešením celého problému.

7 Profesionální sportovci, kteří vykonávají svou činnost ve formě tzv. OSVČ, však mohli žádat stát o kompenzační bonus pro OSVČ, což také ve velké mîre činili.

8 Tento ,intervenční“ legislativní př́istup můžeme v Evropě nalézt např. ve Francii, na Slovensku nebo v Itálii. 
v současnosti především v občanském zákoníku (sportovní praxe v České republice mimo jiné prakticky vyloučila uplatnění pracovních smluv pro vztahy vznikající mezi profesionálními sportovci a kluby, pro něž vykonávají svou sportovní činnost, a tyto vztahy jsou upravovány jako inominátní smlouvy ve smyslu § 1746 odst. 2 OZ). ${ }^{9}$

Vše výše uvedené však neznamená, že by se v České republice ale i v jiných státech, kde existuje naopak rozsáhlejší zvláštní zákonná úprava právních vztahů ve sportu, na smlouvy uzavírané ve sportovním prostředí nevztahovaly obecné právní zásady soukromého práva, přičemž jedním ze zcela zásadních principů je zde klasická zásada pacta sunt servanda. Ta se např. v českém občanském zákoníku vedle dalších ustanovení objevuje v $\$ 3$ odst. 2 písm. d), podle nějž „,daný slib zavazuje a smlouvy mají být splněny“, a dále třeba v $§ 1759$ odst. 1 stanovujícím, že „smlouva strany zavazuje“.

Z výše uvedeného je tedy patrné, že sportovní prostředí není z platnosti těchto obecných právních zásad vyňato, je však i v jeho vlastním zájmu, aby smluvní ujednání byla plněna, a to i mezi kluby a u nich smluvně vázanými sportovci. Na jednu stranu kluby vynakládají nemalé prostředky např. v rámci transferových smluv na to, aby mohly hráče do svého týmu přivést. Mají tudíž zájem na tom, aby hráči následně dodrželi své smlouvy, které s tímto klubem uzavírají, a neodešli bez dalšího předčasně do jiného klubu. Z druhé strany je zde pak zájem hráčů na tom, aby měli dostatečné záruky, že jim bude za řádný výkon sportovní činnosti v mezích jejich nejlepších schopností (tzv. best effort) ze strany klubu po celou dobu poskytováno sjednané protiplnění, tj. zejména vyplácení smluvních odměn. ${ }^{10}$

Samotné sportovní asociace prostřednictvím svých vnitřních předpisů proto zásadu pacta sunt servanda vyzdvihují jako základ pro fungování profesionálního sportu v jejich odvětví. Nejlepším a vůdčím příkladem v tomto směru může být Mezinárodní federace fotbalových asociací („FIFA“), která vzhledem k popularitě a ekonomické síle fotbalu zásady, na nichž jsou postaveny profesionální smlouvy, sama s ohledem na specifika sportovního (fotbalového) prostředí dále rozpracovává. Vzhledem k tomu, že prostřednictvím tzv. členského principu ${ }^{11}$ jsou vnitřními předpisy FIFA vázány nejen všechny národní fotbalové asociace, ale též jejich prostřednictvím všichni aktivní fotbalisté, kluby, popř. další osoby, které mají status člena národní fotbalové asociace, ${ }^{12}$ je dosah této vnitřní regulace dalekosáhlý a pokrývá v důsledku fotbalové prostředí ve všech státech světa.

9 Viz poznámka pod čarou č. 7 výše.

10 Pro hráče je to o to důležitější, že sportovní činnost pro ně obvykle představuje jediný zdroj příjmů (vedle případných dalších požitků, které jsou ale taktéž vázány na výkon sportovní činnosti - velké většině sportovců se např. generují př́ijmy z reklamních činností pouze po dobu jejich aktivní kariéry). V některých profesionálních smlouvách bývá občas i výslovně vyloučena jakákoliv další výdělečná aktivita sportovce bez předchozího souhlasu klubu, což jen podtrhuje závislost sportovce na jeho klubu.

11 Srov. FRITZWEILER, J. - PFISTER, B. - SUMMERER, T. Praxishandbuch Sportrecht. 3. Aufl. München: C. H. Beck, 2014, s. 202 a násl.

12 Podle čl. 9 odst. 4 Stanov FAČR jsou (musí být) členy tohoto spolku třeba i rozhodčí, trenéři, kluboví lékaři atd. Stanovy FAČR - viz Fotbalová asociace. Stanovy 2019. In: FAČR [online]. 2019 [cit. 2021-02-20]. Dostupné na: https://facr.fotbal.cz/uredni-deska-predpisy/231?category=1. 
Ústředním předpisem FIFA pro oblast smluvních vztahů kolem profesionálních smluv ve fotbale jsou FIFA Nařízení o statusu a přestupech hráčů ${ }^{13}$ (FIFA Regulations on the Status and Transfer of Players, dále jen „RSTP“), která zavazují všechny členské asociace FIFA ${ }^{14}$ podle svého čl. 3 písm. b) ,zahrnout do svých predpisủ nástroje na ochranu smluvní stability, a to se zohledněním kogentních ustanovení národního práva a kolektivních smluv [...] “. Napříč RSTP se objevuje celá řada dalších specifických ustanovení týkajících se pravidel zajištění smluvní stability, tj. dodržování sjednaného obsahu a doby trvání profesionálních smluv ve fotbale. $Z$ nich jsou nejpodstatnější povinnosti klubů plnit své finanční závazky vůči hráčům, jakož i povinnost na straně klubů a hráčů dodržet sjednanou dobu platnosti smlouvy a zákaz jejího předčasného vypovězení, ledaže je k tomu dán tzv. „,spravedlivý důvod“ (just cause). ${ }^{15}$ Účelem RSTP je proto nastavit ve fotbale takové prostředí, kde budou profesionální smlouvy uzavírány, plněny a ukončovány podle určitého mezinárodně jednotného standardu, který bude shodný pro fotbalisty a kluby působící v České republice, Španělsku nebo třeba v Argentině. ${ }^{16}$

Zásadního významu zásady pacta sunt servanda pro sport si je vědom též Mezinárodní rozhodčí soud pro sport (Court of Arbitration for Sport, tzv. „CAS“), jenž z této zásady nezřídka vychází při své rozhodovací praxi a konstatuje např. následující: ,, [S]mluvní stabilita je klíčová pro správné fungování mezinárodního fotbalu. Princip pacta sunt servanda se vztahuje na všechny subjekty, ,malé a ,velké" kluby, neznámé i top hráče, zaměstnance a zaměstnavatele, bez ohledu na jejich význam, pozici či sílu. "17

I s ohledem na formální i neformální autoritu CASu u všech dalších relevantních orgánů rozhodujících o závazcích ze smluv ve sportovním světě (tj. především u dalších arbitrážních a kvaziarbitrážních orgánů ve sportovním světě) má tudíž zásada smluvní stability pevně vkořeněné místo v zásadách smluvních vztahů ve sportu.

13 Viz FIFA. Regulations on the Status and Transfer of Players [online]. 2020 [cit. 2021-02-20]. Dostupné na: https://resources.fifa.com/image/upload/fifa-rstp-2020.pdf?cloudid=fhtgqpmkbpe3bvgoej4u.

14 Srov. k tomuto též obecnou povinnost na straně všech členských asociací FIFA respektovat a vůči svým členům vynucovat $\mathrm{v}$ mezích daných národním právním řádem příslušného státu povinnosti plynoucí z předpisů FIFA, tj. i RSTP, jakož i z rozhodnutí orgánů FIFA a Mezinárodního rozhodčího soudu pro sport (Court of Arbitration for Sport, dále jen „CAS“). Tato povinnost všem členům FIFA plyne mimo jiné z čl. 8 odst. 3 a čl. 14 odst. 1 písm a) a d) Stanov FIFA (znění z roku 2020) - viz FIFA. Statues [online]. 2020 [cit. 2021-20-02]. Dostupné na: https://resources.fifa.com/image/upload/fifa-statutes-2020 .pdf?cloudid=viz2gmyb5x0pd24qrhrx.

15 Viz zejména čl. 14 a násl. RSTP.

16 Vždy je však nutné mít na paměti to, že předpisy FIFA nestojí nad obecným národním právem daného státu, a tudíž jakákoliv aplikace RSTP či jiných předpisů FIFA bude možná jen v mezích dispozitivnosti ustanovení př́íslušného národního práva.

17 Viz rozhodnutí CAS ze dne 19. 5. 2009 CAS 2008/A/1519 - FC Shakhtar Donetsk (Ukraine) v/ Mr. Matuzalem Francelino da Silva (Brazil) \& Real Zaragoza SAD (Spain) \& FIFA CAS 2008/A/1520 Mr. Matuzalem Francelino da Silva (Brazil) \& Real Zaragoza SAD (Spain) v/ FC Shakhtar Donetsk (Ukraine) \& FIFA, odst. 80 a 81; dále srov. např. též WITHAGEN, M. - WHYTE, A. De Sanctis and the Article 17: the Last of the Saga? International Sports Law Journal. 2011, Vol. 11, No. 3-4, s. 38 a násl.; DE DIOS CRESPO PÉREZ, J. Arbitration CAS 2007/A/1298 Wigan Athletic FC v/ Heart of Midlothian \& CAS 2007/A/1299 Heart of Midlothian v/ Webster \& Wigan Athletic FC \& CAS 2007/A/1300 Webster v/ Heart of Midlothian. In: WILD, A. (ed.). CAS and Football Landmark Cases. Haag: T. M. C. Asser Press, 2012, s. 77 a násl. 


\section{DOPADY KORONAVIROVÉ KRIZE NA SMLUVNÍ STABILITU PROFESIONÁLNÍCH SMLUV VE SPORTU}

\section{COVID-19 A VÝZVY PRO SMLUVNÍ STABILITU VE SPORTU}

Profesionální sport, který lze dnes již nepochybně považovat za jeden ze sektorů evropské a světové ekonomiky, ${ }^{18}$ je velmi výrazně svázán s časově ohraničenými cykly. Ty jsou vázány na zpravidla předem stanovené sezónní rozpisy soutěží, které jsou do značné míry celosvětově pro př́íslušné sportovní odvětví koordinovány mezinárodními sportovními asociacemi.

Tyto cykly trvají zpravidla jeden rok a jsou spjaty s obdobím, v němž se konají jednotlivé ročníky národních soutěží, mezinárodních kvalifikací a/nebo turnajů. Pro fungování sportu tak, jak jej známe, je rozdělení do soutěžních fází neodmyslitelným organizačním principem, který je dlouhodobě ustálený a s nímž dané sportovní prostředí počítá mnohdy na několik let dopředu (viz třeba tzv. olympijské cykly či systémy kvalifikace na jiné velké mezinárodní soutěže typu mistrovství světa, které se konají jednou za několik let). Z tohoto harmonogramu, který nabral v posledních desetiletích pravidelný chod, vycházely a stále vychází i smluvní vztahy ve sportu. ${ }^{19}$ Jak profesionální smlouvy sportovců, tak i sponzorské dohody či smlouvy týkající se vysílacích práv jsou ve sportovním světě zpravidla předem vázány na období kopírující předvídaný rámcový harmonogram sportovních soutěží, a to i v př́ipadech, kdy jsou tyto smlouvy sjednávány jako víceleté.

Na konkrétním př́kladu fotbalu lze demonstrovat, jak je předem pevně stanovovaný běh času určující pro fungování celého současného systému tohoto sportu. Základním východiskem, na nějž se váže tento systém, je předem daný harmonogram soutěží, který $\mathrm{s}$ přihlédnutím $\mathrm{k}$ mezinárodním fotbalovým termínům stanovují příslušné národní či regionální fotbalové asociace. ${ }^{20} \mathrm{Z}$ něj v profesionálním fotbale vychází nejenom doba, na niž jsou uzavírány profesionální smlouvy s hráči (nehledě na to, že dle regulí FIFA nesmí standardní délka profesionální smlouvy fotbalisty překročit dobu 5 let ${ }^{21}$ ), ale třeba též sjednaná doba pro hostování hráče z klubu A v klubu B. Pravidelnost soutěží je též svázána s předem danými pravidly pro postupy či sestupy klubů mezi jednotlivými soutěžními úrovněmi a pro sponzorské či jiné obdobné smlouvy.

18 Srov. k tomu např. Bílá kniha o sportu Evropské komise ze dne 11. 7. 2007, část 3: The Economic Dimension of Sport (COM(2007) 391).

19 Když byly rozhodnutím Mezinárodního olympijského výboru odloženy olympijské hry plánované do Tokia v roce 2020 na rok 2021, bylo to poprvé od časů druhé světové války, kdy došlo ke změně v časovém plánu konání olympiády. Poprvé v novodobé historii olympijských her však byl důvod jiný než probíhající celosvětový válečný konflikt.

20 Např. pro sezónu 2019/2020 v české nejvy̌̌ší fotbalové lize byl původně předvídán interval od 1. 7.2019 do 30. 6. 2020, přičemž mnoho smluv mělo sjednanou dobu platnosti třeba právě do konce června 2020. Srov. MÁDL, L. Kango, vydrž ještě chvíli: smlouvy končící v červnu mohou být problém. In: Seznam Zprávy [online]. 18. 4. 2020 [cit. 2021-02-20]. Dostupné na: https://www.seznamzpravy.cz/clanek/kango -vydrz-jeste-chvili-smlouvy-koncici-v-cervnu-muzou-byt-problem-100777?fbclid=IwAR1PFGY0Dse 9LT-8x6fwTRVyjFXR-MdmXcMHrnivg5ZnQh6bSWnxwBxkGLg\#utm_content=ribbonnews\&utm _term $=$ Lud $\%$ C4\%9Bk\%20M\%C3\%A1dl\&utm_medium=hint\&utm_source=search.seznam.cz.

21 Čl. 18 odst. 2 RSTP. 
Soutěže (a s nimi i finanční plán klubů) mají také předem dána tzv. přestupová okna, tj. obvykle 2 období ročně, v nichž je možné provádět transfery hráčủ. Do všech těchto starých pořádků vnesla koronavirová pandemie velký zmatek, jelikož začalo kvůli epidemiologické situaci a veřejnoprávním opatřením docházet ke zpoždování soutěží.

Některé národní fotbalové soutěže se rozhodly příslušný ročník raději předčasně ukončit bez odehrání všech původně plánovaných soutěžních kol, ${ }^{22} \mathrm{v}$ jiných případech se po opadnutí první vlny pandemie soutěže se zpožděním a za zvláštních opatření znovu otevřely, avšak s notným časovým skluzem, který vyžadoval prodloužení standardních termínů pro trvání soutěžního ročníku. ${ }^{23}$

At' již došlo k předčasnému ukončení soutěží, nebo k jejich odložení a dohrání až po původně předvídaném závěrečném termínu sezóny, dostávaly se jak kluby, tak potažmo sportovci do nekomfortní situace. Po dobu lockdownu profesionálních soutěží kluby nemohou generovat některé př́íjmy, se kterými ve své finanční rozvaze počítaly. ${ }^{24}$ Kluby proto $\mathrm{v}$ takové situaci musely hledat úspory v projektovaných nákladech a jednou z cest, které se nabízely, bylo i zmenšení výdajů na hráčské odměny.

\section{COVID-19 A REFLEXE PROBLEMATIKY PROFESIONÁLNÍCH SMLUV ZE STRANY FIFA}

FIFA jako zastřešovatel celosvětového fotbalového prostředí si byla těchto problémů v době globální pandemie ${ }^{25}$ velmi dobře vědomá. Způsob, který pro řešení pandemické situace zvolila, se však formoval postupně a prvotní koncepce FIFA, jak k nastalé situaci přistupovat, byla v některých př́ípadech vykládána tak, že FIFA apeluje mimo jiné na automatické prodloužení profesionálních smluv o dobu, o kterou se prodlouží sezóna oproti původnímu plánu.26,27

Takové úvahy se opíraly o FIFA Zásady ohledně právních dopadů COVID-19 ze dne 7. 4. 2020 (dále jen „Zásady“)28 a bližšího výkladového materiálu FIFA ze stejného dne s označením Problematika fotbalové regulace COVID-19 (dále jen „Problematika COVID“), ${ }^{29}$ jež k tomuto uváděly následující: „Navrhuje se, aby [profesionální] smlouvy byly prodlouženy do takového okamžiku, kdy sezóna skutečně skončí. Toto by mělo být $v$ souladu s pưvodním záměrem stran, když byl kontrakt podepisován, a mělo by to zachovat sportovní integritu a stabilitu. [...] Obdobný princip se vztahuje na smlouvy,

22 Srov. např. ligové soutěže v Belgii.

23 Např. Česká republika.

24 Zejména příjmy z vysílacích práv (je-li mechanismus distribuce těchto př́ijmů založen na konkrétním počtu odvysílaných utkání klubu) a dále též příjmy ze vstupného (které jsou však v propadu i po otevření soutěží vzhledem k omezením vstupu fanoušků na stadiony).

25 Světová zdravotnická organizace (World Health Organisation) označila šîrení covidu-19 za pandemii dne 11. 3. 2020.

26 Standardně je fotbalová sezóna ve většině zemí rozepsána na období od 1. 7. do 30. 6. následujícího roku. Vzhledem k opatřením v souvislosti s koronavirem však začínalo být zřejmé již počátkem dubna 2020, že řada soutěží, budou-li vůbec dohrány, se opozdí a sezónu bude nutné prodloužit až do července.

27 Viz MÁDL, $c . d$.

28 FIFA guidelines to address legal consequences of COVID-19. In: FIFA.com [online]. 7. 4. 2020 [cit. 2021-02-20]. Dostupné na: https://www.fifa.com/who-we-are/news/fifa-guidelines-to-address-legal-consequences-of-covid-19.

29 FIFA.COVID-19 Football Regulatory Issues [online]. 7. 4. 2020 [cit. 2021-02-20]. Dostupné na: https:// img.fifa.com/image/upload/zyqtt4bxgupp6pshcrtg.pdf. 
které mají nabýt účinnosti k začátku nové sezóny, tzn. účinnost těchto smluv je odložena do skutečného okamžiku zahájení přiští sezóny. “ Zatímco v tištěné verzi Zásad na webu stála tato informace bez dalšího doplnění, v její videoprezentační formě ${ }^{30}$ již byla uvedena předznamenáním, že veškeré smluvní vztahy jsou v prvé řadě podřízené platnému právnímu řádu příslušné země. ${ }^{31}$ Tento dovětek již celou ideu FIFA staví do realističtějšího světla, jelikož jinak lze zcela souhlasit s názorem generálního sekretáře FAČR Jana Paulyho ml., jenž se na Twitteru vyjádřil, že v českém fotbalovém (a, jak má FIFA/UEFA občas tendence zapomínat, 32 i právním) prostředí je automatické prodlužování hráčských smluv těžko představitelné: „Např. představa plošného prodloužení trvání smluv je za mě řě̌ení vhodné pro [počítačovou hru] FIFA 20, jinak z říše snů. "33

$\mathrm{Z}$ důvodu soukromoprávní povahy závazků mezi profesionálními sportovci a kluby plyne, že jinak než vzájemnou dohodou všech dotčených subjektů nelze dobu účinnosti smluv měnit, ledaže by tak stanovoval eventuálně přímo zákon. K tomu však (nejen) v České republice nedošlo a toto původně diskutované jednostranné, či spíše „,mimostranné“, 34 prodloužení či odklad účinnosti smluv se tudíž v českém a ani zahraničním fotbalovém světě neodehrálo. Kluby tak byly nuceny problematiku prodlužování smluv řešit primárně ve vzájemné dohodě s hráči.

Podobně se nakonec vyvinula situace kolem dalšího bodu Zásad a související Problematiky COVID, který se věnoval možnosti měnit obsah profesionálních smluv. Zde se dá předpokládat, že se cílilo především na případy, kdy klub se vinou pandemie a související ztráty př́ijmů dostal do ekonomické tísně, kterou by chtěl řešit snížením hráčských odměn (tato úprava se však podle výkladového stanoviska FIFA nevztahuje na případy jednostranného vypovídání smluv ${ }^{35}$ ). Zásady k tomu ve své písemné podobě uváděly toto: „V této souvislosti FIFA důrazně doporučuje klubiom a hráčùm, aby společně usilovali o nalezení dohod a řešení během doby přerušení soutěží. Přestože to je primárně na př́islušných stranách na národní úrovni, aby nalezly řěsení odpovídající okolnostem v jejich vlastním státu, FIFA doporučuje zaměřit se na všechny aspekty příslušné situace [...]. “ Citovaná pasáž Zásad je sice stylizována vágně, oproti předchozímu bodu týkajícímu se prodlužování smluv je však realističtější či pregnantněji formulována $v$ tom směru, že bere do úvahy realitu právních řádů jednotlivých států,

30 Dostupný pod identickým odkazem jako písemné znění Zásad.

31 Obdobně odkaz na nutnost souladu s národním právem obsahuje i Problematika COVID. Zde se uvádí, že jednostranné změny smluv budou v případě sporu uznány jen tehdy, pokud neodporují národnímu právu a kolektivním smlouvám a jsou činěny v dobré vîre, rozumně a proporcionálně.

32 Srov. KOHOUT, D. (Mezinárodní) sportovní asociace na pomezí soukromého a veřejného: kde jsou limity jejich ingerence do společenských vztahů? In: GERLOCH, A. - ŽÁK KRZYŽANKOVÁ, K. Právo v měnícím se světě (30 let: retrospektiva 1989-2019 - Perspektiva 2020-2050). Plzeň: Aleš Čeněk, 2020, s. 433-454.

33 Twitter Jana Paulyho ml. (@honza_pauly) dne 15. 4. 2020. (Další vyjádření Jana Paulyho v podobném duchu jsou citována též in MÁDL, $c . d$.).

34 „Mimostranné“ prodloužení smlouvy je míněno ve smyslu toho, že by se zakládalo na autoritativním rozhodnutí soukromoprávního subjektu, který není stranou smlouvy (tj. na rozhodnutí zastřešující sportovní asociace).

35 Viz bod 16 tzv. FIFA. COVID-19 Football Regulatory Issues - FAQ [online]. 11. 6. 2020 [cit. 2021-02-20]. Dostupné na: https://resources.fifa.com/image/upload/codiv-19-football-regulatory-issues-faqs .pdf?cloudid=wsmwqqhkqxcffkkptk0p. 
jimiž se smlouvy fotbalových profesionálů řídí a které mohou limitovat prostor pro jednostranné změny (a zpravidla tak činí).

Lze shrnout, že v př́padě úpravy délky trvání (účinnosti) či vzájemného plnění po dobu lockdownu soutěží se sportovní prostředí vydalo cestou úpravy profesionálních smluv dohodou, kde podle dostupných indicií hráči na tyto změny formálně vzato dobrovolně přistupovali. To, že $\mathrm{k}$ tomu někdy patrně docházelo s menší ochotou, lze vyčíst z prohlášení uveřejněného na webu České asociace fotbalových hráčů, která je jedním ze subjektů (spolků), které v českém prostředí reprezentují sportovce. Ta na svých stránkách uvedla: „Úvodem je nutné ř́ci, že profesionální i amatérské fotbalové soutěže $v \check{C} R$ jsou pouze přerušeny a odloženy, nikoliv zrušeny, a že tento stav nemá jakýkoliv vliv na platnost profesionálních hráčských smluv. Kluby z tohoto di̊vodu nemaji právo hráčské smlouvy jednostranně ukončovat ani měnit jejich podmínky. Pokud se tak kluby na hráče obrací s požadavkem na krácení odměny, musí k tomu dojít dohodou za výslovného souhlasu hráče, kluby si nemohou nic vynucovat. Z našeho pohledu pro krácení odměn hráčù není důvod, nebot' hráči nadále plní své povinnosti viǒci klubům, i když se v této době jedná hlavně o dodržování individuálního tréninkového plánu. Stávající situace navíc již má zásadní dopad na odměny hráčù, nebot' v jejich odměňování hraje velkou roli prémiová složka (bonusy za vítězné či odehrané zápasy, vstřelené branky apod.), která v současné době samozř ejmě nevzniká a hráčùm náleží pouze základní výše odměny. I pokud se hráči rozhodnou vyjít klubu vstříc, není opodstatněné, aby souhlasili s krácením odměny na dlouhé období, jak se již v některých př́padech stalo a hráči akceptovali snižení dokonce po dobu 6 měsícü. "36

Přes tuto kritiku však realita vedla jinou cestou a výjimečných př́ípadů, které dospěly až před nějaký rozhodčí orgán, je zatím s ohledem na princip nullo actore, nullus iudex ${ }^{37}$ poskrovnu a týkaly se nikoliv dohod o modifikaci smluvních podmínek, nýbrž př́ípadů jednostranného předčasného ukončování smluv s odkazem na vy̌̌ší moc (viz níže).

\section{COVID-19 JAKO VIS MAIOR PRO PLNĚNÍ Z PROFESIONÁLNÍCH SPORTOVNÍCH SMLUV}

Lze se domnívat, že FIFA ve svých dokumentech ze dne 7. 4. $2020^{38}$ skutečně uvažuje, že mohou nastat př́ípady, kdy bude obsah profesionální smlouvy (tzn. obsah vzájemných práv a povinností) měněn jednostranně. Jak jsme poukázali výše, tyto jednostranné zásahy do smluvní stability jsou z pohledu obecného práva sporné a lze je připustit pouze tehdy, pokud původní „,předcovidové“ znění smlouvy něco takového $\mathrm{v}$ obecné rovině připouštělo. ${ }^{39} \mathrm{~V}$ opačných případech by z hlediska právního (bez ohledu na předpisy FIFA) šlo nikoliv o jednostrannou změnu smlouvy, nýbrž o její porušení se všemi možnými důsledky z toho plynoucími. I pokud by např. FIFA vydala

36 Stanovisko ČAFH k přerušení fotbalových soutěží a krácení odměn hráčů. In: Česká asociace fotbalových hráču [online]. [cit. 2021-02-20]. Dostupné na: http://www.milujemfotbal.cz/aktuality /stanovisko-cafh-k-preruseni-fotbalovych-soutezi-a-kraceni-odmen-hracu/66.

37 „Kde není žalobce, tam není soudce“.

38 Tzn. v Zásadách a v Problematice COVID.

39 Nebo eventuálně pokud by právní řád, kterým se smlouva ř́íí, toto umožňoval i bez ohledu na smluvní ujednání. 
jednoznačnou instrukci všem svým členským asociacím, že mají pro profesionální smlouvy, které jsou u nich registrované, připustit či vynucovat jejich jednostrannou změnu, šlo by o instrukci z hlediska obecného smluvního práva irelevantní. Výjimky z imperativní zásady soukromého práva pacta sunt servanda není oprávněna stanovovat žádná soukromoprávní asociace, nýbrž takové případné výjimky mohou plynout pouze přímo ze zákona či v jeho mezích z dvoustranného ujednání smluvních stran. ${ }^{40}$ Jinými slovy bylo by nepřiměřeně právně aktivistické připustit, že obsah již uzavřené smlouvy se může změnit jinak než s jasným, určitým a (alespoň po formální stránce) svobodným projevem obou smluvních partnerů, tj. hráče a klubu.

Pokud se však vrátíme k počáteční hypotéze dané v předchozím odstavci, tj. že je možné, že některé smlouvy obsahovaly od počátku ustanovení o tom, že některá ze stran může za určitých okolností obsah svých závazků ze smlouvy jednostranně měnit, či dokonce smlouvu vypovědět, pak jsou ale některé principy formulované v Zásadách velmi podstatné. ${ }^{41}$ Jedná se totiž především o případy, které existující smlouvy mohou označovat jako „př́pady vis maior“ a které je však potřeba vždy v konkrétním případě jejich invokace náležitě odůvodnit, aby obstály v případě eventuálního sporu o př́ípustnost jejich uplatnění.

Nejdůležitějším předpisem FIFA zabývajícím se stabilitou profesionálních smluv jsou výše zmiňovaná FIFA Nařízení o statusu a přestupech hráču (RSTP). RSTP již ve svém znění platném před pandemií covidu-19 poukazovala na př́pady, kdy mohou být ze strany FIFA modifikovány podmínky smluvní stability v případech vyšší moci. Toho si všímají i Zásady, když poukazují na to, že „čl. 27 RSTP uvádí, že př́ípady vyšší moci mají být posouzeny Radou FIFA, jejiž rozhodnutí jsou konečná. Situace kolem COVID-19 je sama o sobě př́pad vyšší moci pro FIFA a pro fotbal.“42

Touto cestou se pro profesionální kluby i hráče otevírá cesta $k$ aktivnějšímu využívání možnosti jednostranné změny smluv z důvodu vyšší moci. Využití doložky vis maior je a vždy bude chůzí po tenkém ledě, na němž hrozí uklouznutí, které pak může mít tvrdé následky. Pokud by totiž nebyl ve skutečnosti dủvod vyšší moci dán a smlouva by tak byla např. změněna bezdůvodně, a tudíž neoprávněně, hrozí nejenom z hlediska RSTP, ${ }^{43}$ ale i obecného práva sankce pro subjekt, který takto smlouvu porušil. ${ }^{44}$

Z tohoto důvodu FIFA ve svých Zásadách uvádí některá kritéria, která by měla subjektu, který ve výjimečných př́ípadech, kdy nelze jít cestou vzájemné dohody, svědčit, aby jednostranný zásah do smlouvy byl z hlediska FIFA pravidel legitimní: ${ }^{45}$

„Pokud se strany nedokážou dohodnout a následně se př́pad dostane před [orgány] FIFA, skutečnosti, které budou posuzovány, budou zahrnovat toto:

40 V zemích, kde se smlouvy řídí předpisy pracovního práva, lze připustit ještě určitou relevanci kolektivních smluv.

41 Znovu je ale potřeba upozornit na to, že Zásady se nevztahují na případy jednostranných ukončení smluv, zabývají se pouze jednostrannými změnami smluv.

42 FIFA, COVID-19 Football Regulatory Issues, s. 2.

43 Včetně př́ípadné možnosti vypovědět jednostranně smlouvu s tzv. just cause.

44 Srov. ustanovení čl. 17 RSTP.

45 Jak bylo již uvedeno, musí ale být možnost jednostranné změny/výpovědi smlouvy stanovena již přímo ve smlouvě samotné, aby z hlediska obecné legality vůbec mělo smysl o těchto př́ípadech relevantně uvažovat (minimálně ve světle českého práva, obdobně to ale bude platit pro většinu právních řádů, kterými se ta která profesionální smlouva řídí). 
- jestli byl dán skutečný pokus [genuine attempt] ze strany klubu dosáhnout dohody s hráčem;

- jaká je ekonomická situace klubu;

- proporcionalita jakýchkoliv změn smlouvy vůči hráči;

- čistý př́jem hráče po jakékoliv úpravě smlouvy;

- zda bylo s hráčem zacházeno v rovnosti či nikoliv."

Výše uvedené cílí př́edevším na kluby, ale je vhodné podotknout, že hypoteticky může okolnost vyšší moci chtít uplatnit i hráč, a to třeba s ohledem na zdravotní či bezpečnostní rizika $v$ příslušném státě, byt' ve většině případů bude tento institut zajímavý spíše právě pro šetřící kluby. Dále je vhodné ještě v tento okamžik upozornit na to, že v profesionálních smlouvách bývá eventuálně pamatováno na force majeure obvykle spíše jen s ohledem na výpovědní důvody, a nikoliv jako důvod pro jednostrannou změnu smlouvy (při jinak zachování její účinnosti). Přitom Zásady a Problematika COVID se naopak vztahují pouze na prrípady jednostranných změn smluv, a nikoliv na jejich jednostranné výpovědi (zde FIFA vychází nadále z premisy, že smlouvy mají být zachovány, ledaže je nějaký jiný důvod, který by opravňoval vypovězení smlouvy s tzv. just cause $\left.{ }^{46}\right)$.

Pokud bychom tedy v krátkosti shrnuli všechna výše uvedená kritéria využití institutu vyšší moci z hlediska fotbalových profesionálních smluv, pak by měla být respektována tato standardní posloupnost:

a) Možnost jednostranné změny smluvních ustanovení či vypovězení smlouvy je ve smlouvě obecně předvídána, nebo ji ve zcela výjimečných př́ípadech připouští přímo právní řád, jímž se smlouva řídí.

b) Jednostranná změna je odůvodněna zdokladovatelnými faktickými skutečnostmi (z pohledu pandemické situace a/nebo ekonomické stránky), tj. je zdokladovatelný př́ípad vyšší moci a jeho dopad na konkrétní subjekt a jeho právní vztahy.

c) Jednostranná změna je proporcionální, tj. k řešení faktických skutečností (bod b) výše) nešlo zvolit méně invazivní postup a současně není vůči danému sportovci diskriminativní. ${ }^{47}$

V př́ípadě sporu bude na straně, která okolnost vyšší moci uplatnila, aby kumulativní splnění všech naznačených bodů před rozhodujícím orgánem prokázala.

O tom svědčí také judikatura CASu a Komory pro řešení sporů FIFA (FIFA Dispute Resolution Chamber - „FIFA DRC“) věnující se uplatnění principu vis maior. FIFA DRC se již $\mathrm{k}$ otázkám vyšší moci částečně stihla vyjádřit $\mathrm{v}$ rozhodnutí $\mathrm{z}$ období po začátku pandemie, kde uvedla: „, [...] FIFA neprohlásila, že propuknutí COVID-19 je případ vy̌šsi moci v kterémkoliv konkrétním státu nebo území nebo že jakákoliv konkrétní pracovní nebo transferová smlouva byla dotčena stavem vy̌̌ši moci. Jinými slovy v jakémkoliv sporu je na straně, která se dovolává vy̌šsi moci, aby doložila existenci takové události ve světle aplikovatelného právalpravidel, stejně jako di̊sledky s ní

46 Čl. 14 a násl. RSTP.

47 Princip rovného zacházení lze v tomto kontextu chápat tak, že by neměl klub snížit smluvní odměnu tř̌eba jen části hráčského kádru, zatímco zbytku by zachoval plnou výši odměn. Na druhou stranu je možné se domnívat, že by třeba mohlo $\mathrm{v}$ některých případech obstát, kdyby třeba hráčům $\mathrm{s}$ vyššími př́ímy byla odměna snížena o vyšší procentní podíl oproti hráčům, jejichž standardní př́ijem by byl jen minimální. 
spojené. Analýza, zda byl př́pad vyšši moci dán, musí být provedena případ od př́padu se zvážením všech relevantních okolností. “48

I (ještě předkoronovirová) judikatura CASu dotýkající se vyšší moci je v tomto ohledu konzistentní a je spíše zdrženlivá, přičemž břemeno prokázání případu vyšší moci a jejích dopadů na konkrétní subjekty je na straně toho, kdo se jí dovolává. ${ }^{49}$ Jako př́klad lze poukázat třeba na rozhodnutí CASu z roku 2015: „V každém př́padě nelze koncept force majeure aplikovat, pokud strana situaci zavinila. [...] Jako obecné pravidlo lze uvést, že za některých mimořádných a vzácných okolností může být strana, která nesplní své smluvní povinnosti, zproštěna odpovědnosti za toto porušení, pokud prokáže, že porušení nastalo z di̊vodu výskytu události nebo překážky, která je nejen mimo kontrolu (a které nešlo odvrátit), ale také které nešlo rozumně předvídat $v$ době, kdy strana na sebe vzala povinnost, která byla porušena. [...] Nicméně rozhodovací praxe CASu také varovala, že ,podmínky pro uplatnění force majeure je nutno vykládat úzce, jelikož force majeure přináší výjimku ze závazného charakteru obligace (CAS/2006/A/1110)."50

Výše nastíněná pravidla fotbalového prostředí tak aktuálně dále konkretizují již dlouhodobě existující judikaturu sportovních rozhodčích soudů a jsou velmi systematická a logická. Lze mít za to, že budou proto silou fakticity a přsesvědčivosti nalézat i v dalších sportech svá uplatnění.

$\mathrm{Na}$ rozdíl od fotbalu neexistuje $\mathrm{v}$ mnoha dalších sportech dokument obdobný k RSTP, takže bude mnohem více záležet na konkrétní podobě smluvních ujednání ohledně force majeure. Není proto důvod vyloučit $\mathrm{v}$ př́ípadech jiných sportů to, aby se výše uvedenými zásadami poměřovaly i případy jednostranných výpovědí smluv $\mathrm{z}$ titulu vyšší moci. ${ }^{51} \mathrm{~V}$ českém sportovním prostředí rezonovala kauza týkající se extraligového hokejového klubu Mountfield Hradec Králové.

Hokej v České republice se vydal v době jarní vlny pandemie jiným směrem, než tomu bylo u fotbalu, a rozhodl o předčasném ukončení sezóny. ${ }^{52}$ Toto rozhodnutí s sebou pochopitelně přineslo významné dopady na jednotlivé kluby ve sportovní i ekonomické rovině. Hradecký Mountfield odhadl propady př́ijmů na zhruba 8-12 milionů korun. ${ }^{53}$

48 Rozhodnutí FIFA DRC ze dne 20. 7. 2020, Nikolay Bodurov v. Esteghlal, odst. 15 a 16.

49 Srov. MILANOVIC, L. - BERGANT RAKOCEVIC, V. COVID-19: the Impact On Players' Contractual Rights \& Obligations (Key Principles From Case Law). In: LawInSport [online]. 30. 3. 2020 [cit. 2021-02-20]. Dostupné na: https://www.lawinsport.com/topics/item/covid-19-the-impact-on-players-contractual-rights -obligations-key-principles-from-case-law. I tito autoři poukazují na důležitost toho, aby byla možnost změny obsahu či předčasného jednostranného ukončení smlouvy z důvodu vis maior rámcově ve smlouvě předvídána.

50 Rozhodčí nález CAS ze dne 9. 10. 2015, CAS/2015A/3909 Club Atlético Mineiro v. FC Dynamo Kyiv, odst. 66 a 71 .

51 Zatímco FIFA striktně omezila působnost Zásad a Problematiky COVID pouze na př́ípady jednostranných změn smluv a pravidla pro jednostranné předčasné ukončování smluv ponechala v platnosti v podobě, ve které platila před covidem-19, tak pro ostatní sporty takovéto limity neplatí a ani před koronavirovým obdobím neuplatňovaly systém výpovědí s , just cause“ a ,without just cause “, tj. vždy záleželo na posouzení toho kterého případu, zda podle smluvní úpravy a zákonných pravidel je předčasné vypovězení akceptovatelné.

52 Viz Rozhodnutí Výkonného výboru Českého svazu ledního hokeje. In: Český hokej [online]. 11. 3.2020 [cit. 2021-02-20]. Dostupné na: https://www.ceskyhokej.cz/clanky/rozhodnuti-o-zruseni-vyrazovaci -casti-tipsport-extraligy?seasonId=2020.

53 Viz informace na klubovém webu: Prezident klubu Miroslav Schön představuje úsporná opatření. In: Hokejový klub Mountfield Hradec Králové [online]. 6. 4. 2020 [cit. 2021-02-20]. Dostupné na: https://www .mountfieldhk.cz/clanek.asp?id=Prezident-klubu-Miroslav-Schon-predstavuje-usporna-opatreni-9882. 
Nelze se proto př́liš divit, že nastalá situace mohla (nejen) hokejový klub z Hradce Králové nasměrovat k úvahám o úsporných opatřeních, a to včetně zásahů do hrášských smluv. Oficiální informace z klubu hovoří o tom, že s devíti hráči byla dosažena dohoda o snížení odměn, zatímco zbytku kádru byly odměny zachovány v plné výši ${ }^{54} \mathrm{~V}$ jiných př́ípadech však došlo přímo $k$ jednostrannému ukončení hráčských smluv, což se týkalo celkem pěti hráčủ. Nutno podotknout, že možnost vypovědět profesionální smlouvu v českém profesionálním hokeji je dána již tzv. standardizovanou (vzorovou) profesionální smlouvou v čl. IX odst. 3, který stanovuje toto: „Nemožnost Klubu dostát svým povinnostem plynoucím z této Smlouvy (i) z důvodu vyšši moci (válka, živelní pohroma apod.), (ii) z důvodu přerušení Ligy, které se Klub účastní, a/nebo (iii) z důvodu ztráty oprávnění Klubu ke sportovní činnosti, jež vykonává ke dni uzavření této Smlouvy, je pro Klub di̊vodem k výpovědi této Smlouvy. “55

Tohoto ustanovení Mountfield také využil vůči zmíněným pěti hráčům. Kauza se z iniciativy některých z těchto propuštěných hráčů zaštitovaných Českou asociací hokejistů (dále jen „CAIHP“) $)^{56}$ dostala před Smírčí komisi Českého svazu ledního hokeje (dále jen „ČSLH“" $)^{57}$ jakožto orgánu př́ślušnému v rámci spolkové autonomie tento typ sporů řešit. ${ }^{58} \mathrm{Ta}$ v rozhodnutí ze dne 21.4. $2020^{59}$ učinila některé podstatné závěry, jež korelují s pohledy na tuto oblast podle výkladových stanovisek FIFA i judikatury CASu či FIFA DRC debatovaných výše. Konkrétně Smírčí komise shledala toto: „,[K] naplnění prededmètného ustanovení [ $\mathrm{tj}$. čl. IX odst. 3 smlouvy] je nutné, aby nastala alespoň jedna z tř́ v něm uvedených skutečností a současně aby tato skutečnost vedla $v$ bezprostřední př́činné souvislosti k objektivní nemožnosti dostát smluvní povinnosti klubu. Uplatnění výpovědi je striktně limitováno naplněním obou podmínek.

Jak komise zdi̊raznila, pandemie a s ní související omezení představují nade vši pochybnost vyšš moc, tedy jednu z ve smlouvě uvedených podmínek. Na druhé straně nebylo klubem nijak doloženo, že by uvedená skutečnost měla za následek objektivní nemožnost dostát jeho smluvním závazkům. Podle názoru komise lze stěží prokázat, že by tato nemožnost vznikla výlučně vůči několika hráčùm, u nichž klub smluvní ustanovení uplatnil. Pochybnosti vyvolává i to, že zhruba ve stejné době převzal klub nové finanční závazky vůči jiným hráčum.

54 Tamtéž.

55 Standardizovaná smlouva využívaná plošně profesionálními kluby je dostupná online: Hráčská smlouva [online]. [cit. 2021-02-20]. Dostupné na: https://www.ceskyhokej.cz/data/document/file/hracska_smlouva _140226.pdf. K této problematice srov. blíže ZBOŘIL, L. Právní ochrana profesionálních hokejistů. Právní rádce [online]. 9. 10. 2020 [cit. 2021-02-20]. Dostupné na: https://pravniradce.ihned.cz/c1 -66826110-pravni-ochrana-profesionalnich-hokejistu.

56 Blíže viz Česká asociace hokejistů [online]. [cit. 2021-02-20]. Dostupné na: http://www.caihp.cz/.

57 Blíže viz Český hokej [online]. [cit. 2021-02-20]. Dostupné na: https://www.ceskyhokej.cz/.

58 Srov. čl. 30 odst. 2 písm. b) Přestupního řádu Českého svazu ledního hokeje [online]. [cit. 2021-02-20]. Dostupné na: https://www.ceskyhokej.cz/data/document/file/5-prestupni-rad-pro-kluby-extraligy-a-i.-ligy -zmeny-schvalene-vv-cslh-od-konference-23.6.2018-.pdf.

59 Rozhodnutí není bohužel veřejně dostupné, zde podaný komentář tak reflektuje přehled rozhodnutí podávaný na stránkách České asociace hokejistů - viz CAIHP slaví velký úspěch: smírčí komise ČSLH zneplatnila výpovědi dvou hráčů Mountfield HK. In: Česká asociace hokejistů [online]. 21. 4. 2020 [cit. 2021-02-20]. Dostupné na: http://www.caihp.cz/caihp-slavi-velky-uspech-smirci-komise -cslh-zneplatnila-vypovedi-hracu-mountfield-hk/. 
Podle vyjádření smírči komise ČSLH musí být také ve výpovědi skutkově vymezen její dìvod, a to tak, aby jej bylo možné zjistit a v př́padě nutnosti řádně přezkoumat. Ve výpovědích použitá formulace, z di̊vodu vyšši moci - rozhodnutí VV ČSLH z 12.3. 2020 o ukončení ročníku soutěže ELH 2019-2020“s odkazem na obecné a variantní ustanovení smlouvy tento požadavek jednoznačně nesplňují. Již z uvedeného di̊vodu proto dospěla komise $k$ závěru, že výpověd’ nesplňuje podmínky stanovené hráčskou smlouvou a je tudíz neplatná."60

Nutno podotknout, že kauza týkající se propuštěných hradeckých hokejistů nebyla zcela ojedinělá, podobný případ řešila Smírčí komise i ve vztahu k jiným klubům. ${ }^{61}$

Lze mít za to, že tímto úhlem pohledu se český hokejový orgán přihlásil k principům vyšší moci, které obdobně nazírá i CAS či orgány FIFA (včetně předkoronavirové epochy) a které vymezila třeba též FIFA již v citovaných Zásadách ze dne 7. 4. 2020. V české hokejové kauze tak nacházíme poukaz minimálně na to, že každý případ musí být přezkoumatelný s ohledem na jeho individuální povahu, že okolnost koronavirové pandemie nesmí být zneužita arbitrárně jen vůči některým hráčům a že klub musí být připraven řádně doložit, že jeho ekonomická situace neumožnila smlouvu v původní podobě dodržet.

\section{COVIDOVÁ DOLOŽKA V RÁMCI PROFESIONÁLNÍCH SMLUV VE SPORTU A JEJÍ MOŽNÉ PODOBY}

Z výše popsaných případů, jak sportovní prostředí reagovalo na (zejména) ekonomické dopady koronavirové pandemie na profesionální sport, lze předvídat, že budeme svědky dalšího vývoje smluvní úpravy těchto vztahů. I za předpokladu, že se zdravotní rizika spojená s koronavirem budou postupně celosvětově snižovat, je realistické uvažovat, že se subjekty působící v profesionální sportovní sféře z této lekce poučí a budou se snažit na ni pamatovat již rovnou pro futuro v rámci sjednaných smluvních podmínek v profesionální smlouvě. Nemusí jít jen o zakotvení zvláštních smluvních ujednání pro případ samotné koronavirové nákazy, nýbrž o obecné rozšřr̃ení důvodů charakteru „vis maior" ve vztahu k ukončování smluv či přechodnému snížení smluvní odměny. Hlavní otázkou je, jak takovéto „covidové doložky“ vhodně nastavit, aby nebyly v rozporu s obecně platnými právními principy a pro obě smluvní strany byly důvody jejich uplatnění srozumitelné a akceptovatelné.

${ }^{60}$ Rozhodnutí smírčí komise ČSLH - Šidlík, Žejdl, Mountfield HK. In: Český hokej [online]. 3. 5. 2020 [cit. 2021-02-20]. Dostupné na: https://www.ceskyhokej.cz/clanky/rozhodnuti-smirci-komise -cslh-sidlik-zejdl-mountfield-hk?seasonId=2018.

61 Srov. informace z webu CAIHP ohledně kauzy týkající se HC Energie Karlovy Vary a hráče Vojtěcha Poláka: CAIHP dosáhla dohody mezi Vojtěchem Polákem a HC Energie Karlovy Vary. In: Česká asociace hokejistů [online]. 11. 6. 2020 [cit. 2021-02-20]. Dostupné na: http://www.caihp.cz/caihp-dosahla -dohody-mezi-vojtechem-polakem-a-hc-energie-karlovy-vary/ (zde byla kauza uzavřena smírem před Smírčí komisî). Jeden z hradeckých hokejistů se pak u Smírčí komise objevil ještě podruhé, nebot' mu Mountfieldem byla smlouva po rozhodnutí Smírčí komise vypovězena znovu, i tentokrát byl však ve sporu tento hráč Lukáš Žejdl úspěšný - viz Výpověd’ pro Lukáše Žejdla zrušena podruhé. In: Česká asociace hokejistů [online]. 20. 6. 2020 [cit. 2021-02-20]. Dostupné na: http://www.caihp.cz /vypoved-pro-lukase-zejdla-zrusena-podruhe/. 
Na první pohled se zdá, že takovéto doložky budou ve prospěch především klubů. Avšak při obecném zamyšlení se je třeba si uvědomit, že pokud by došlo na vážné ekonomické potíže klubů, pak by to mělo dlouhodobé důsledky pro celé fungování příslušného sportovního odvětví, a tím třeba i dorůstající generace budoucích profesionálních fotbalistů, hokejistů, házenkářo atd.

Do té míry, do jaké covidové doložky nebudou odporovat obecným právním zásadám, jako jsou ochrana dobré víry, zákaz zneužití práva či zákaz zneužití silnějšího postavení v rámci smluvních vztahů ${ }^{62}$ je věcí smluvních stran, aby si v mezích dispozitivnosti soukromého práva sjednaly, jak bude jejich profesionální spolupráce vypadat. ${ }^{63}$ Jak bylo nastíněno výše, na formulaci znění profesionálních i dalších smluv ve sportu však mohou mít v jisté míře vliv též interní normativní předpisy sportovních asociací.

Z pohledu budoucí standardizované úpravy situací podobných, jako je/byla ta koronavirová, lze proto předvídat dvě základní metody jejich reflexe. Ty se pravděpodobně budou v jisté míre i navzájem prolínat a odkazovat jedna na druhou.

V prvé řadě lze v obecné rovině očekávat, že hlavně velké národní či mezinárodní sportovní asociace začnou přijímat bud’ komplexnější specifické vnitřní předpisy upravující případy výluky, či omezení soutěží z důvodů vis maior (tj. koronavirus a další celostátně či celosvětově závažné situace ovlivňující sportovní prostředí). Tato pravidla pak budou působit vi̊či smlouvám, které budou pro futuro přijímány po nabytí účinnosti zmiňovaných spolkových regulí. Tím mohou sportovní asociace působit na sjednocování smluvních dokumentů v rámci svého pole působnosti. Jak jsme diskutovali výše, je ovšem těžko myslitelné, aby takováto pravidla autoritativně měnila znění již existujících smluv. ${ }^{64}$

Další možnou rovinou je, že si kluby budou s hráči sjednávat koronavirové doložky ve smlouvách samostatně, popř̀. nad rámec minimálních standardů daných sportovní asociací je budou dále rozpracovávat.

Otázkou je, jak správně covidovou doložku naformulovat. Tuto otázku si budou nepochybně klást právníci např́ič různými smluvními oblastmi, pro sportovní prostředí by mělo být vhodné ji vázat na některé sportovní kategorie. Z globálního hlediska se v interních předpisech mezinárodních sportovních asociací budeme setkávat s obecnými formulacemi, které budou muset být aplikovány národními sportovními asociacemi $\mathrm{v}$ sepjetí s obecným právním rámcem $\mathrm{v}$ př́íslušném státě. V rámci konkrétní smluvní úpravy v českém sportu by se jevilo jako nejvhodnější vázat uplatnění covidové doložky

62 Viz $\$ 6, \S 8$ či $\S 433$ OZ.

$63 \mathrm{~V}$ tomto ohledu je myšleno především na situaci v České republice, kde sportovci, jak již bylo uvedeno, nevykonávají svou činnost v rámci pracovněprávního vztahu. Na rozdíl od zemí, kde sportovci působí jako zaměstnanci svých klubů a kde případně působí i odborové organizace sportovců, tak v České republice panuje mnohem větší flexibilita co do právního základu těchto smluvních vztahů (viz nepojmenované smlouvy dle $\$ 1746$ odst. 2 OZ).

64 Způsob, jak mohou pravidla celonárodních či mezinárodních sportovních spolků ovlivňovat obsah v budoucnu uzavíraných smluv, je dán tím, že tyto asociace mají oprávnění profesionální smlouvy registrovat. Teprve registrací získává hráč oprávnění nastupovat v soutěžích za klub, s nímž uzavřel profesionální smlouvu. Bude-li stanoveno, že profesionální smlouvy musí obsahovat ustanovení týkající se plnění v době výluky soutěží pod sankcí toho, že smlouva nesplňující tyto podmínky nebude sportovní asociací registrována, je to jednoznačnou motivací pro smluvní strany, aby tato pravidla daná shora řídící asociací respektovaly. 
na okolnosti spočívající v přerušení či ukončení soutěží v souvislosti s opatřeními přijatými orgány veřejné moci.

Jinou alternativou, která má ale ze své podstaty též původ v opatřeních přijímaných orgány státu, je povinnost hrát profesionální soutěže tzv. ,,bez diváků“ či jen s omezenou kapacitou diváků v hledišti. I to se samozřjmě negativně promítá do ekonomické bilance klubů, které přicházejí o příjmy ze vstupného, s nimiž počítali v rámci své předsezónní ekonomické rozvahy. Na druhou stranu př́ijmová složka klubu je jeho ,,podnikatelským rizikem“" a nesouvisí s tím, zda a jak si hráč plní své smluvní povinnosti. V tomto druhém směru by tudíž aplikace covidové doložky nebyla příliš přiléhavá a ospravedlnitelná za předpokladu, že hráč se účastní všech tréninkových i soutěžních aktivit klubu.

Jako příklad lze uvést takto formulovanou ,covidovou doložku“, jejíž naplnění vychází z předpokladu, že dojde po určitou dobu k přerušení, či dokonce k předčasnému ukončení sezóny: ${ }^{65}$

„1. Klub a hráč sjednávají, že pro případ, bude-li ligová soutěž (dále jen, soutěž‘), jǐž se účastní A-Tým mužư, ${ }^{66}$ přerušena $v$ di̊sledku opatření či rozhodnutí orgánu veřejné moci v případech vyšši moci (zejména epidemie, živelná pohroma, válečný konflikt), bude základní měsíční odměna hráče dle článku XY této Smlouvy krácena následovně:

a) o $20 \%$ v prvních dvou měsících, v nichž došlo k tomuto přerušení soutěže;

b) $\quad 40 \%$ v dalších dvou měsících, v nichž nad rámec písm. a) tohoto článku došlo k tomuto přerušení soutěže;

c) o $50 \%$ za každý další měsíc, v němž nad rámec písm. a) a b) tohoto článku došlo k tomuto přerušení soutěže;

2. Za jeden měsíc se ve smyslu odst. 1 tohoto článku považuje doba 30 dní. Jestliže přerušení soutěže podle odst. 1 tohoto článku trvá pouze část př́islušného kalendářního měsíce, bude měsíční odměna hráče dle článku XY této Smlouvy krácena přiměreně za každý den trvání přerušení soutěže. Obdobně budou posuzovány též př́ipady, kdy během jednoho kalendářního měsíce dojde ke kumulativnímu překročení časových rozmezí podle odst. 1 písm. a) až c) tohoto článku.

3. Pokud dojde v jednom soutěžním ročníku k opakovanému přerušení soutěží, doby přerušení soutěži se pro účely posuzování krácení odměny podle odst. 1 tohoto článku sčítají.

4. Pokud dojde ke zrušení celého soutěžního ročníku či k jeho předčasnému ukončení $v$ důsledku opatření či rozhodnutí orgánu veřejné moci podle odst. 1 tohoto

65 Nezohledňuje tudíž další faktory, jako je omezení možnosti tréninků a dalších mimosoutěžních aktivit, stejně jako další opatř̌ení mající dopad na finanční situaci klubu (např. zmiňovaná povinnost hrát soutěže bez diváků). Navržená doložka vychází z toho, že ačkoliv dojde k výluce v pořádání soutěží, tak sportovci nadále plní přinejmenším část svých smluvních povinností, jako je individuální či kolektivní příprava, poskytnutí osobnostních práv k využití klubem atp. Autorovi tohoto článku se proto nejeví jako přiměřené zcela v plné výši vyloučit výplaty odměn sportovcům za současného dalšího trvání smlouvy. V takovém případě by se jako jediné přijatelné řešení nabízelo vypovězení smlouvy ex nunc (pokud by vypovídající strana dokázala splnit podmínky pro tento postup stanovené ve smlouvě a z doktrinálního hlediska rozebírané v tomto článku výše).

66 Popř. zde lze formulovat jiný způsob určení, pro jaké soutěže musí být výluka vyhlášena, aby se aktivovala tato doložka. 
článku, krátí se odměna hráče o $50 \%$ až do doby pưvodně stanoveného konce sezóny podle rozpisů soutěží.

5. Klub je povinen hráče písemnou formou ${ }^{67}$ informovat o tom, že začíná krátit měsíční odměny podle tohoto článku Smlouvy, a to nejpozději do 5 dní ode dne, od kterého má být krácení odměny klubem uplatněno. Tato informace musí obsahovat odkaz na opatření či rozhodnutí příslušného orgánu veřejné moci a př́padně též /název zastřěsující sportovní asociace 68 \%, na jejichž základě došlo k přerušení soutěže. Pokud klub povinnost podle tohoto odstavce v uvedené lhütě nesplní, není oprávněn odměny hráče krátit až do okamžiku prokazatelného informování hráče o zahájení krácení měsíčních odměn podle tohoto článku Smlouvy; v takovém případě se však krácení odměny nemůže vztahovat na období předcházející tomuto okamžiku prokazatelnému informování hráče. V připadě opakovaného přerušení soutěží podle odst. 3 tohoto článku, musí klub povinnost dle tohoto odstavce splnit v každém jednom případě přerušení soutěží."

Navrhovaná vzorová covidová doložka je koncipována jednak s přihlédnutím k ekonomickým potřebám klubů, jednak s ohledem na zajištění alespoň elementární ochrany slabší smluvní strany, tedy hráčů. Jeví se jako vhodné účinnost koronavirových doložek vázat na existenci vyšší moci a především opatř̌ení či rozhodnutí orgánu veřejné moci. 69 Pokud by byla klauzule formulována bez této podmínky, mohla by se spekulativně stát zneužitelným nástrojem ze strany klubů či organizátorů soutěží.

Lze podotknout, že podobně nastavená bývají i současná smluvní ustanovení týkající se postupného snižování odměn hráčům v př́ípadě jejich zranění souvisejícího se sportovní činností. ${ }^{70}$ Právě v tomto aspektu lze spatřovat jedno z nejvýraznějších oslabení pozice profesionálních sportovců v České republice (OSVČ) ve srovnání s postavením klasických zaměstnanců. Nicméně vycházíme-li z přetrvávajících specifik českého sportovního prostředí, lze se domnívat, že v případě covidových doložek se může smluvní praxe inominátních profesionálních smluv ubírat právě tímto směrem v analogii k úpravě postupného snižování odměn během zranění sportovce, kdy nemůže sportovní činnost pro klub vykonávat.

Uvedené percentuální rozvržení je pochopitelně pouze modelové a subjekty činné v profesionálním sportu si budou nastavovat různé hranice. Neměly by však spustit ze zřetele to, že i po dobu přerušení soutěží, či dokonce předčasného ukončení sezóny hráč nadále musí plnit řadu ustanovení smlouvy a klub též zpravidla disponuje určitou částí osobnostních práv hráče, ${ }^{71}$ která může finančně zhodnocovat.

67 Lze doplnit, jakou formou konkrétně (např. emailem, dopisem do vlastních rukou, osobně s podpisem hráče o tom, že byl řádně informován atp.).

68 Např. FAČR apod.

69 Zejména hygienické správy, ministerstev, vlády.

70 Srov. např. čl. VI odst. 1 písm. a) Vzorové hráčské smlouvy pro extraligu a 1. ligu ledního hokeje pod Českým svazem ledního hokeje: „Nebude-li Hráč schopen plnit své povinnosti plynoucí z této Smlouvy ze zdravotních di̊vodi̊, jejichž př́ičinou jsou skutečnosti uvedené níže pod písm. a), b) a/nebo c) tohoto odstavce 1, náleži Hráči Základní odměna v následující výši: a) v případě, že se Hráč zraní v utkání Klubu nebo na tréninku Klubu v prípravě na utkání Ligy: 1.-4. týden - 100 \% Základní odměny, 5.-7. týden $70 \%$ Základní odměny, 8.-10. týden - 60 \% Základní odměny, 11. - ...týden - 50 \% Základní odměny [...].“ (Hráčská smlouva).

71 Např. fotografie hráčů, propagační videa s jejich záběry, faksimile podpisu atp. 
Jiným prístupem, který se zdá být z hlediska české právní úpravy obecně akceptovatelným, je jiný režim rozložení smluvního plnění klubem vůči hráčům. V obecné praxi zpravidla alespoň na vrcholné úrovni v největších sportech v ČR převládají doposud smlouvy, které stanovují základní fixní odměnu náležící hráči za určité časové období (zpravidla za jeden měsíc) a dále určují, že hráči budou vyplaceny další smluvní odměny s ohledem na jeho individuální či týmovou výkonnost a úspěchy. ${ }^{72}$ Doposud lze mít za to, že převládají smlouvy, které jsou založeny na pevné složce smluvní odměny (garantované) bez ohledu na výkonnost,$^{73} \mathrm{kde}$ bonusová složka je pouze (mnohdy velmi zajímavou) přidanou hodnotou celého kontraktu. Vzhledem k nejistotám, kterým bude sportovní sektor v souvislosti s koronavirovou epidemií čelit, je možné, že řada klubů ve zvýšené mîre při sjednávání nových profesionálních smluv půjde cestou smluv zaručujících spíše nižší fixní základ odměny, avšak úměrně tomu budou navýšeny možné bonusové složky. Tento přístup však nepochybně bude spojen s ekonomickou situací všech klubů v době během a po koronakrizi. Je zřejmé, že pro hráče se jeví uzavření takto nastavené smlouvy jako méně výhodné, proto lze očekávat, že pokud by se k tomuto postupu ve větší mîre uchýlily jen některé kluby, znamenalo by to jejich znevýhodnění na „trhu s hráči“, jelikož by se staly ve srovnání s jinými kluby (a to př́ípadně i těmi v zahraničí) méně lákavými ,zaměstnavateli“.

I přes výslovné sjednání těchto covidových doložek v rámci budoucích profesionálních smluv nelze očekávat, že by jejich uplatňování (podle očekávání především ze strany klubů) nebylo napadáno bud před sportovními rozhodčími orgány, nebo před obecnými či mezinárodními soudy. ${ }^{74} \mathrm{Je}$ tak důležité, aby podobně jako v př́ípadu spojeném s hradeckými hokejisty nebyla ustanovení o ukončení či přechodné změně obsahu smlouvy (právu hráče na odměnu) využívána selektivně (tj. diskriminačně) napříc hráčským kádrem. To neznamená, že by si nešlo představit, že např. elitní hráč týmu, který pobírá mnohem větší smluvní odměnu než hráč na „černou práci“, by měl předem sjednáno vyšší procento snížení obvyklé měsiční odměny pro prŕípad mimořádné celospolečenské krize než ostatní „běžni““ členové hráčského kádru. I to by z pohledu autora tohoto článku naplňovalo principy předvídatelnosti, smluvní stability i volnosti i samotného účelu takového ujednání, kterým je především ekonomické přežití klubu za současného poskytnutí základní obživy smluvně vázanému hráči. Avšak případy, kde by docházelo jednostranně ze strany klubu ke snižování odměny, či dokonce předčasnému ukončování smluv jen u některých selektivně určených hráčů, aniž by to bylo zcela objektivně

72 Z hlediska individuálních výkonů hráče mohou být tyto odměny sjednávány např. pro př́pad odehrání určitého počtu minut $\mathrm{v}$ jednom utkání, počtu odehraných soutěžních zápasů v sezóně celkem, podle počtu vstřelených gólů, vychytaných čistých kont atp. Kolektivní výsledky, které bývají zohledňovány v rámci bonusových složek smluvních odměn, jsou např. dosažené body týmu v soutěžních zápasech, kvalifikace do evropských pohárů, zisk mistrovského titulu či určité pozice v konečné tabulce soutěže. Srov. též KOHOUT, D. Smluvní pokuty plynoucí ze smluv o profesionálním výkonu sportovní činnosti. In: PICHRT, J.TOMŠEJ, J. (eds.). Odměňování v právních souvislostech. Praha: Wolters Kluwer, 2020, s. 81.

73 To platí zcela jistě pro většinu prověrených profesionálů (tzv. established players), u hráčů, jejichž budoucí výkonnost je pro kluby větší neznámou, může již dnes být smlouva nastavena především na bonusové složce a základní fixní odměna je nižší (např. tzv. try-out players).

${ }^{74}$ Lze se domnívat, že takové otázky by se mohly objevit i před Soudním dvorem EU (sport je totiž v tomto ohledu nezpochybnitelně ekonomickou aktivitou, otázkou je zásada nediskriminace a rovnosti atp.) či před Evropským soudem pro lidská práva (v sepětí se zákazem diskriminace). 
a spravedlivě zdůvodnitelné, by těžko mohlo obstát v rámci následně vzniklých sporů před soudy či rozhodčími orgány. Okolnost, že by bylo nemožné uplatnit tyto důvody selektivně, by pak bránila klubům předčasně vypovídat v době předčasného ukončení či přerušení soutěží jednostranně profesionální smlouvy, protože by se to z jejich pohledu rovnalo sportovní sebevraždě. Jinými slovy by nemohly ,propustit“ jen část svých hráčů, nýbrž by takto museli přistoupit ke všem členům týmu, čímž by však ztratili jakoukoliv konkurenceschopnost (a i důvěryhodnost) v okamžiku obnovení soutěží.

Závěrem této části lze ještě doplnit, že i samotná okolnost, zda je dána situace vyšší moci odůvodňující změnu standardních smluvních práv a povinností, může být do budoucna předmětem přezkoumávání nezávislým orgánem. Institut smluvně zakotveného vis maior by se proto neměl nadužívat třeba pro případy ekonomické krize klubu nesouvisející s celospolečensky významnou negativní událostí typu celosvětové pandemie, jelikož to by naopak šlo proti základnímu principu smluvní stability pacta sunt servanda.

\section{ZÁVĚR}

V rámci analýzy předkládané v tomto př́íspěvku jsme se zabývali dopady koronavirové pandemie na profesionální sport, a to v mezinárodním kontextu se zvláštním přihlédnutím k poměrům v České republice.

Koronavirus představoval a nadále představuje významný zásah do fungování sportu a ovlivňuje zásadním způsobem i profesionální hráčské smlouvy. Vzhledem k propadům $\mathrm{v}$ př́ijmech klubů bylo $\mathrm{v}$ řadě případů přistoupeno ke snižování smluvních odměn hráčů, či dokonce $\mathrm{k}$ předčasnému vypovídání těchto smluv. V tomto příspěvku bylo proto diskutováno, zda a případně za jakých bližších podmínek může k těmto zásahům do smluvní stability ve sportu legálně docházet, aniž by některá ze stran byla vystavena sankcím za porušení smlouvy, obecného právního řádu či předpisů sportovních asociací (zde byl podrobněji rozebírán především případ fotbalu).

V úvahách je potřeba rozlišovat smlouvy, které byly uzavřeny v době před pandemií covidu-19, a smlouvy, které budou uzavírány teprve po jejím propuknutí. Dalším kritériem pro hodnocení možných důsledků je to, zda smlouva sama předvídá případy vyšší moci a jaké možnosti v takovém případě dává stranám.

Institut vyšší moci, ${ }^{75}$ který se v této situaci uplatňoval a, bude-li tento stav trvat, tak patrně i po nějakou dobu se ještě bude uplatňovat, je právním konceptem, který však

75 V českém občanském zákoníku je pro př́ípady podstatné změny okolností pro realizaci smluvních vztahů dána podpůrná úprava v $\$ 1765$ odst. $1 \mathrm{OZ}$ (pokud si strany neujednaly přímo ve smlouvě, jak budou v př́ípadě vyšší moci postupovat): „Dojde-li ke změně okolností tak podstatné, že změna založí v právech a povinnostech stran zvlášt' hrubý nepoměr znevýhodněním jedné z nich bud' neúměrným zvýšením nákladů plnění, anebo neúměrným snížením hodnoty předmětu plnění, má dotčená strana právo domáhat se vioči druhé straně obnovení jednání o smlouvě, prokáže-li, že změnu nemohla rozumně předpokládat ani ovlivnit a že skutečnost nastala až po uzavření smlouvy, anebo se dotčené straně stala až po uzavření smlouvy známou. Uplatnění tohoto práva neopravňuje dotčenou stranu, aby odložila plnění. "Patří se však doplnit, že aplikovatelnost tohoto ustanovení mohly strany vyloučit a že v případě, kdy jednání o smlouvě nepovedou k dohodě, je možno se obrátit na soud, aby svým rozhodnutím změnil závazky plynoucí ze smlouvy tak, aby se v rámci smluvního vztahu obnovila rovnováha (pro sportovní prostředí však tato soudní cesta nebude vhodná pro svou očekávatelnou zdlouhavost). Eventuálně může na případy vis maior 
nemá mít bezbřehé či arbitrární uplatnění. Nejsou-li případy vyšší moci podrobněji ve smlouvě rozpracovány, což by byla jinak vhodnější varianta, je nutné se při dovolávání obecně formulované klauzule o vyšší moci zaměřit na uspokojivé zdůvodnění jejího uplatnění, které by obstálo i v případném sporu. Navíc lze očekávat, že uplatnitelnost obecně formulované doložky vyšší moci bude s postupem času ve vztahu ke koronavirové pandemii slábnout a nebude se již týkat smluv nově uzavíraných po jejím propuknutí, jelikož v těchto případech již postrádají okolnosti koronaviru do značné míry atribut „nepředvídatelnosti“. Strany smlouvy totiž již mohly okolnosti pandemie a související plošně přijímaná opatření vzít dostatečně v potaz již při přípravě smlouvy. $\mathrm{Z}$ tohoto pohledu bude proto podstatné, aby smlouvy, které se na vis maior odkazují, výslovně formulovaly, že za případ vis maior považují právě i epidemii. ${ }^{76}$

Bude tedy stěžejní, jak se případy výluk či prodloužení, nebo naopak zkrácení sezón upraví přímo ve smlouvě, popř. jak se strany dokážou dohodnout na dodatku smlouvy, který by takovouto nastalou situaci reflektoval tehdy, pokud to strany profesionální smlouvy opomněly udělat již v prvotním smluvním ujednání. Tento druhý postup je však z hlediska smluvní jistoty a stability komplikovanější.

Jak je argumentováno a navrhováno v tomto textu, lze doporučit zakotvit do budoucna do smluv v profesionálním sportu covidové doložky, které by obě strany připravovaly na situace, které mohou v tomto ohledu nastat. Výše formulované vzorové návrhy takovýchto doložek mají posloužit jako základní inspirace, kterou si však smluvní strany budou dále uzpůsobovat či doplňovat. Týká se to procentuální sazby snížení sjednané odměny, časového určení, kdy k úpravě práv a povinností dochází, či okolností, za nichž k ní dochází. 77

V dalším vývoji proto bude určující to, jak si případ koronaviru (epidemie obecně) strany předem ve smlouvě vymezí. Pokud tak neučiní, budou v př́ípadě potřeby odkázány na jednání o změně smlouvy, nebot' její obsah nelze měnit jinak než ze svobodné vůle obou stran. ${ }^{78}$

\author{
JUDr. David Kohout, Ph.D. \\ Právnická fakulta Univerzity Karlovy \\ kohout@prf.cuni.cz
}

doléhat též ustanovení § 2913 odst. 2 OZ stanovující, že „, [p]ovinnosti k náhradě se škủdce zprostí, prokáže-li, že mu ve splnění povinnosti ze smlouvy dočasně nebo trvale zabránila mimořádná nepředvídatelná a nepřekonatelná překážka vzniklá nezávisle na jeho vi̊li “.

76 Toto komentuje O. Uraz takto: „Dochází-li již k plošnému rozšiřování koronaviru, nelze jej již vnímat jako vis maior [ve smyslu zákonného ustanovení v \$ 1765 odst. 1 OZ], nebot'v době uzavírání smlouvy již tato nákaza nesplňovala požadavek ,nepředvídatelnosti ‘ (není splněno, že dodavatel tuto překážku nemohl při uzavírání smlouvy předvídat), tudíž by se neaplikovaly ani smluvní ustanovení o překážce vyšši moci a ani zákonná ustanovení normující vis maior. " (URAZ, O. Koronavirus a smlouvy 2020 (porušení, následky, odstoupení). In: ARROWS [online]. 13.3. 2020 [cit. 2021-02-20]. Dostupné na: https://www.arws .cz/novinky-v-arrows/koronavirus-a-smlouvy-2020-poruseni-nasledky-odstoupeni). Obdobně též BŘÍZA, P. Koronavirus jako důvod neplnění smluvních povinností v domácím i přeshraničním obchodním styku, aneb lze pozdní dodávku ospravedlnit virem? In: epravo.cz [online]. 4. 3. 2020 [cit. 2021-02-20]. Dostupné na: https://www.epravo.cz/top/clanky/koronavirus-jako-duvod-neplneni-smluvnich-povinnosti-v -domacim-i-preshranicnim-obchodnim-styku-aneb-lze-pozdni-dodavku-ospravedlnit-virem-110791.html.

77 Návrhy jsou navíc formulovány s vědomím, že profesionální smlouvy sportovců v České republice nepodléhají v drtivé většině ustanovením zákona č. 262/2006 Sb., zákoník práce. Pro pracovněprávní smlouvy by tato doporučení přebírat bez dalšího nebylo vhodné.

78 Jak bylo poukázáno výše a pomineme-li možnost podle $§ 1766$ OZ. 